Article

\title{
A New Direction for Biomining: Extraction of Metals by Reductive Dissolution of Oxidized Ores
}

\author{
D. Barrie Johnson *, Barry M. Grail and Kevin B. Hallberg \\ College of Natural Sciences, Bangor University, Deiniol Road, Bangor LL57 2UW, UK; \\ E-Mails: b.m.grail@bangor.ac.uk (B.M.G.); kevinhallberg@sky.com (K.B.H.) \\ * Author to whom correspondence should be addressed; E-Mail: d.b.johnson@bangor.ac.uk; \\ Tel.: +44-1248-382358; Fax: +44-1248-370731.
}

Received: 27 November 2012; in revised form: 11 January 2013 / Accepted: 22 January 2013 /

Published: 30 January 2013

\begin{abstract}
Biomining, the biotechnology that uses microorganisms to extract metals from ores and concentrates, is currently used exclusively for processing reduced ores and mine wastes. Metals of economic value also occur extensively in oxidized ores, such as nickel laterites. While these are not amenable to oxidative dissolution, the ferric iron minerals they contain can, in theory, be disrupted by iron reduction, causing associated metals to be released. We have harnessed the ability of the facultatively anaerobic, acidophilic bacterium Acidithiobacillus ferroooxidans to couple the oxidation of elemental sulphur to the reduction of ferric iron in the goethite fraction of a limonitic nickel ore at $30^{\circ} \mathrm{C}$. Nickel and other metals ( $\mathrm{Co}, \mathrm{Cr}$ and $\mathrm{Mn}$ ) were effectively solubilised and maintained in solution due to the low $\mathrm{pH}$ (1.8) of the leach liquor. The results highlight the potential for the bioprocessing of oxidized, iron-rich ores using an approach that is energy-saving and environmentally-benign compared with metallurgical processes currently applied to the extraction of $\mathrm{Ni}$ from lateritic ores.
\end{abstract}

Keywords: oxide ores; bacteria; bioleaching; metal recovery; reduction

\section{Introduction}

Bioprocessing of metal ores and mineral concentrates has, over the past 50 years, developed from a low-key technology ("dump" leaching of waste rocks at copper mines in the USA) to far more controlled and sophisticated operations involving irrigated and aerated heaps (of up to $10 \mathrm{~km}^{2}$ at the Escondida 
mine in Chile) and temperature-, aeration- and $\mathrm{pH}$-controlled stirred tanks, each typically $\sim 1000 \mathrm{~m}^{3}$ in size [1,2]. Global production of $\sim 20 \%$ copper, $\sim 5 \%$ gold and smaller amounts of other metals is currently achieved through bioprocessing. The metal-hosting minerals in ores and concentrates currently amenable to biomining are all reduced and mostly sulphidic. These contain either the target metal (such as copper in the mineral chalcopyrite, $\mathrm{CuFeS}_{2}$ ) or else enshroud precious metals (such as gold in refractory pyritic ores) and, therefore, need to be removed to allow chemical extraction (e.g., using cyanide in the case of gold). The "bio" components in biomining are some specialized microorganisms that are able to accelerate the oxidative dissolution of the sulphide minerals in extremely acidic liquors. The main process is the continuous regeneration by iron-oxidizing bacteria and archaea of ferric iron, which degrades sulphide minerals, while biological oxidation of the sulphur moiety in the minerals generates sulphuric acid, thereby maintaining acidic conditions that enhance both the solubilities of cationic metals and the activities of the acidophilic microorganisms involved. A third tier of acidophilic bacteria and archaea maintains the stabilities and robustness of mineral leaching consortia by metabolizing organic carbon originating from the primary producers [3]. Since the energy required by the primary and secondary mineral-degrading microorganisms is the reduced iron and sulphur present in the minerals themselves and the dominant leaching bacteria and archaea are autotrophic, the only extraneous requirements for heap and tank operations are for some inorganic salts (agricultural fertilizer is often used for this), air (for both oxygen and carbon dioxide) and water.

Base and precious metals can also occur in ores that are partially or totally oxidized, such as nickel laterites, which represent the major nickel resource in the lithosphere, accounting for an estimated $72 \%$ of residual reserves [4]. Nickel laterites typically comprise two distinct horizons: a limonite zone near the surface that contains mainly hydrated iron oxides and relatively little magnesium and a lower saprolite zone that is dominated by hydrous magnesium silicates. Limonites are formed during laterisation when weathering near the surface results in the oxidation and precipitation of iron. Nickel and cobalt, derived from the weathering process of parent rock material, are incorporated into the lattice structure of precipitated hydrated iron oxides, either by co-adsorption or substitution for iron, producing a modified goethite mineral of typical composition $\left(\mathrm{Fe}_{0.97}, \mathrm{Ni}_{0.03}, \mathrm{Co}_{0.003}\right) \mathrm{O} \cdot \mathrm{OH}$.

The intimate association of base metals with ferric iron minerals in limonites means that these ores are not amenable to processing by conventional oxidative mechanisms employed in biomining. Hydrometallurgical or pyrometallurgical processes are currently used to break the iron-oxygen bond, thereby releasing the associated nickel, but these are typically high energy- and/or reagent-requiring processes [5,6]. Although bioprocessing of nickel laterites has previously been explored (using either iron-chelating organic or strong mineral acids produced as by-products of microbial metabolism), slow rates and low yields of nickel extraction have precluded these approaches being developed as commercial operations.

The past 25 years or so has seen a large increase in the number of bacteria that are known to respire on ferric iron in anoxic environments, including many that live in highly acidic environments [7]. The acidophilic bacterium, Acidithiobacillus ferrooxidans, is well-known for its ability to oxidize ferrous iron in the presence of oxygen, though this prokaryote is a facultative anaerobe that can also grow anaerobically using ferric iron as its electron acceptor. Specific rates of iron reduction of this and related bacteria tend, however, to be much lower than those of specific iron oxidation [8]. We have explored the possibility that iron reduction carried out at low $\mathrm{pH}$ by At. ferrooxidans could be used to 
mediate the dissolution of ferric iron minerals present in nickel laterites, thereby facilitating the solubilisation and recovery of the nickel and other metals of economic interest present in the ore. Such an approach represents, in essence, a reverse of the processes involved in conventional biomining.

\section{Results and Discussion}

\subsection{Characteristics of the Limonitic Nickel Laterite Ore}

The low-grade nickel limonite used in this study was fractioned into two sizes of particles: "milled" ore to $<1 \mathrm{~mm}$, which was used for initial screening experiments, and "crushed" ore to $<6 \mathrm{~mm}$, which was used in subsequent bioreactor experiments. Mineralogical analysis (Table 1) showed that the ore consisted mainly of quartz (76\%, by weight) and goethite (10\%), as well as minerals containing $\mathrm{Al}, \mathrm{Cr}$, $\mathrm{Mn}$ and $\mathrm{Ni}$. The Ni content of the ore was $0.4 \%$ (by weight) and was associated mainly with the goethite $(56 \%)$, quartz (19\%) and magnesium silicate (18\%) phases. Other metals present in the ore included chromium $(0.27 \%)$, manganese $(0.13 \%)$ and cobalt $(0.04 \%)$.

Table 1. Dominant mineral phases of the nickel laterite ore used in this study and the deportment of $\mathrm{Ni}$ to those minerals. The Ni concentration in the laterite ore was $0.4 \mathrm{wt} \%$.

\begin{tabular}{lccc}
\hline Mineral & Generalized formula & wt \% of ore & $\begin{array}{c}\text { Nickel deportment } \\
\text { (\% of total Ni) }\end{array}$ \\
\hline Goethite & $\mathrm{FeO}(\mathrm{OH})$ & 10 & 56 \\
Quartz & $\mathrm{SiO}_{2}$ & 76 & 19 \\
(Serpentine) & $\mathrm{Mg}_{3} \mathrm{Si}_{2} \mathrm{O}_{5}(\mathrm{OH})_{4}$ & 2 & 18 \\
Asbolane & $\mathrm{Mn}_{3} \mathrm{O}_{3}(\mathrm{OH})_{6}$ & 0.6 & 7 \\
Chromite & $\mathrm{FeCr}_{2} \mathrm{O}_{4}$ & 0.8 & 0 \\
\hline
\end{tabular}

\subsection{Reductive Dissolution of Goethite in the Laterite Ore and Solubilization of Associated Nickel} under Controlled Conditions

The acidophilic mesophile At. ferrooxidans was selected for scaled-up experiments, since its ability to use an inorganic (and relatively low cost) electron donor (sulphur) was considered to be an overriding factor in a full-scale process, compared to heterotrophic iron-reducing acidophiles (e.g., Acidiphilium spp.) that require organic sources of energy. In addition, although reductive dissolution is inevitably a proton-consuming reaction and addition of acid is necessary to maintain the $\mathrm{pH}$ of the process, net acid consumption is less when sulphur is used as an electron donor compared to an organic donor, such as glucose [shown in Equations (1) and (2), which are normalized on a molar basis, for the amount of goethite reduced].

$$
\begin{array}{r}
24-\mathrm{FeO} \cdot \mathrm{OH}+4 \mathrm{~S}^{\circ}+40 \mathrm{H}+\rightarrow 24 \mathrm{Fe}^{2+}+4 \mathrm{SO}_{4}{ }^{2-}+32 \mathrm{H}_{2} \mathrm{O} \\
24-\mathrm{FeO} \cdot \mathrm{OH}+\mathrm{C}_{6} \mathrm{H}_{12} \mathrm{O}_{6}+48 \mathrm{H}^{+} \rightarrow 24 \mathrm{Fe}^{2+}+6 \mathrm{CO}_{2}+42 \mathrm{H}_{2} \mathrm{O}
\end{array}
$$

When anaerobic cultures were set up in $\mathrm{pH}$ - and temperature-controlled bioreactors, At. ferrooxidans again catalyzed the reductive dissolution of goethite and consequent solubilisation of nickel in the ore (Figure 1). The strong correlation $\left(R^{2}=0.93\right)$ between the amount of ferrous iron and nickel in solution (Figure 2a) was in agreement with the mineralogical analysis of the ore, which had 
indicated that the majority of the nickel present was associated with goethite. Moreover, the ratio between the amount of sulphuric acid consumed to maintain $\mathrm{pH}$ of the leach liquor at 1.8 and that of iron solubilised (1.75:1; Figure 2b) was close to the theoretical relationship (1.7) in Equation (1), given that the dominant form of dissolved sulphate at $\mathrm{pH} 1.8$ is $\mathrm{HSO}_{4}{ }^{-}$, rather than $\mathrm{SO}_{4}{ }^{2-}$. In contrast, the relationship between proton consumption and iron solubilised is 3:1 when goethite dissolution proceeds entirely via acid dissolution [Equation (3)].

$$
24-\mathrm{FeO} \cdot \mathrm{OH}+72 \mathrm{H}^{+} \rightarrow 24 \mathrm{Fe}^{3+}+48 \mathrm{H}_{2} \mathrm{O}
$$

The fact that reductive dissolution of goethite was essential for the effective solubilization of nickel from the ore was confirmed when one of the bioreactors was operated in aerobic mode. In this case, rates of solubilisation of nickel and iron were far slower than when conditions were anaerobic, but otherwise, identical (Figure 1). The small amount of nickel that was released under aerobic conditions (which was similar to that which occurred in non-inoculated anaerobic cultures) was probably associated with the magnesium silicates in the laterite, as these would be predicted to dissolve in acidic liquors. Similar amounts of nickel and iron were solubilised in sterile anaerobic reactors, as in inoculated aerobic bioreactors, and again, all of the iron that was solubilised was present as ferric.

Figure 1. Changes in concentrations of soluble iron $(\square, \square)$ and nickel $(\diamond, \diamond)$ in bioreactor cultures of At. ferrooxidans containing Ni laterite ore and elemental sulphur, incubated either under anoxic (solid symbols) or aerobic (open symbols) conditions.

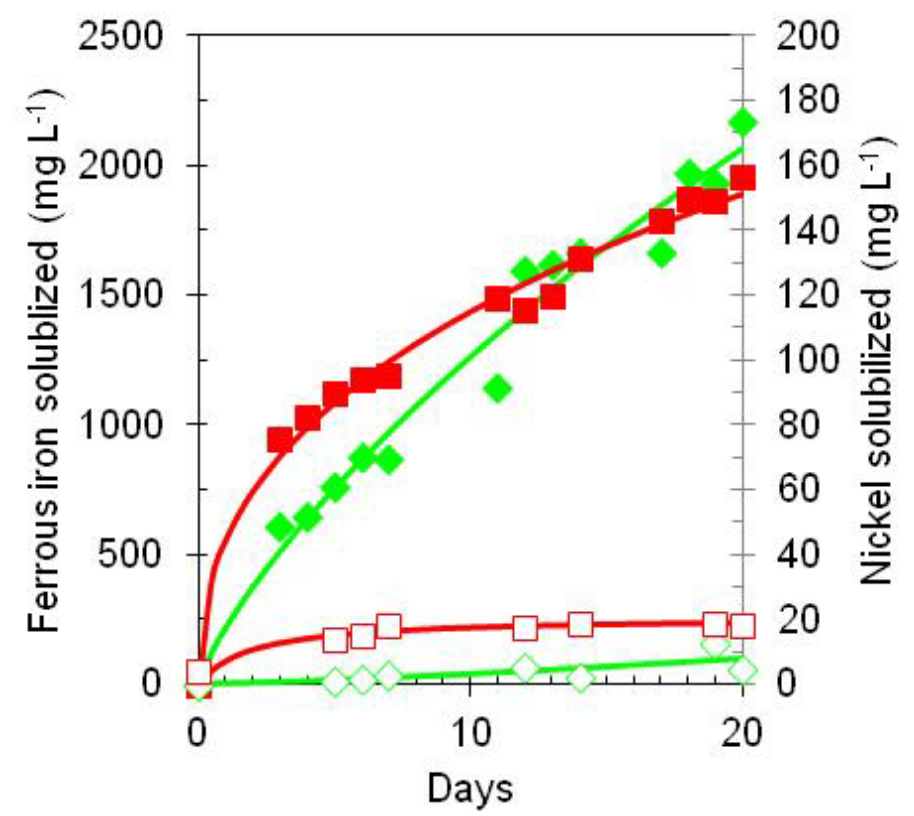


Figure 2. (a) Correlation between iron and nickel solubilised from Ni laterite ore by At. ferrooxidans incubated under anoxic conditions and using elemental sulphur as electron donor; (b) correlation between iron released from the Ni laterite ore and the amount of sulphuric acid consumed in maintaining $\mathrm{pH}$ at 1.9 , in anoxic cultures.

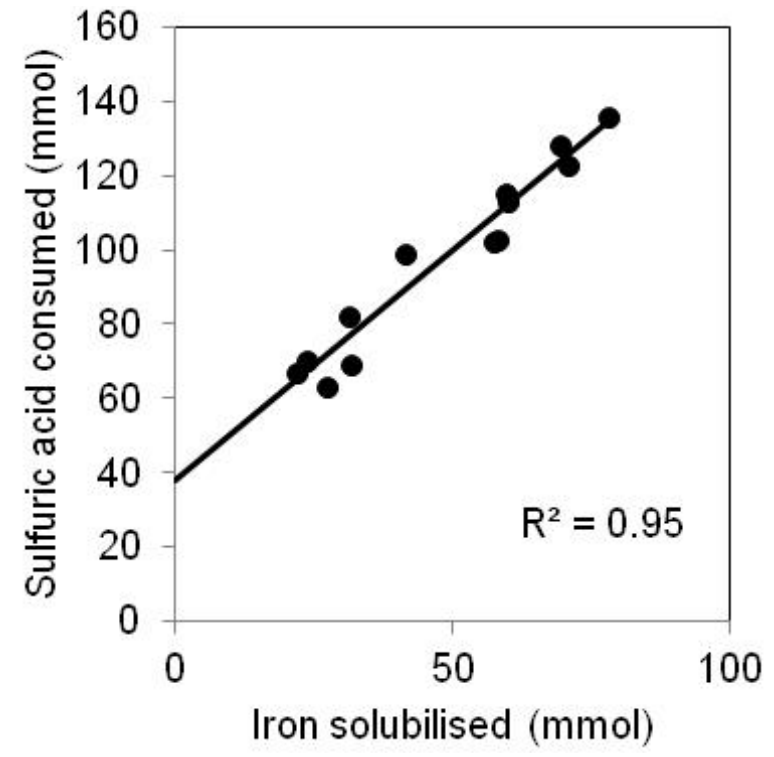

(a)

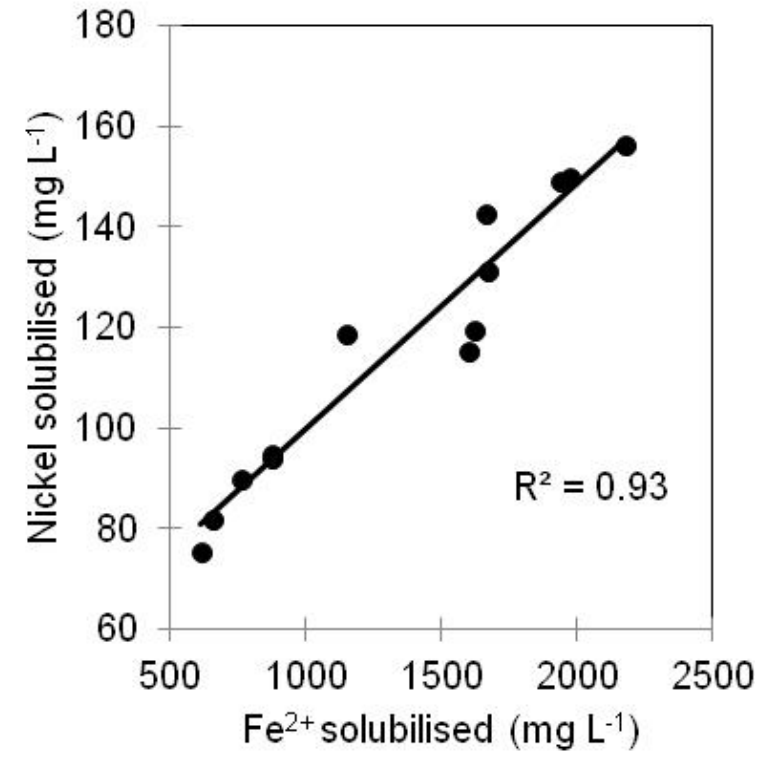

(b)

Previously, it has been proposed that acidophiles accelerate the destruction of oxidized iron minerals under anaerobic conditions by reducing the small amounts of soluble ferric iron produced by acid dissolution of these minerals, thereby causing a shift in the equilibrium between solid-phase and soluble ferric iron [9]; Equation (4), which is consistent with the current observations.

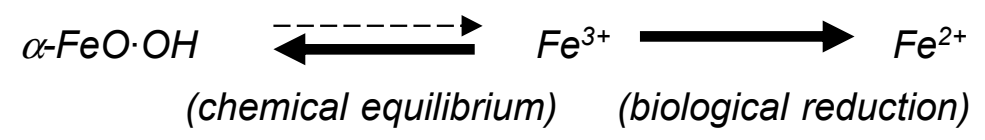

\subsection{Solubilization of Other Transition Metals Present in the Laterite Ore}

In addition to the solubilization of iron and nickel, concentrations of both soluble manganese and cobalt also increased as bioleaching of the laterite ore progressed (Figure 3a). The source of these two transition metals in the ore is the oxyhydroxide mineral asbolane $\left((\mathrm{Ni}, \mathrm{Co})_{x} \mathrm{Mn}(\mathrm{O}, \mathrm{OH})_{4} \cdot \mathrm{nH}_{2} \mathrm{O}\right)$. The oxidation state of manganese in asbolane is +4 and, as its empirical formula indicates, it commonly contains both nickel and cobalt within its lattice structure. Concentrations of soluble manganese were highly correlated with those of cobalt during dissolution of the nickel laterite ore $\left(R^{2}=0.93\right.$; Figure 3b). Since $\mathrm{Mn}(\mathrm{IV})$ is highly insoluble in $\mathrm{pH} 1.8$ liquors, the implication is that asbolane was also subjected to reductive dissolution. In order to elucidate the mechanism of asbolane dissolution, the laterite ore was incubated in sterile acidic growth medium under aerobic conditions, in the absence or presence of $\mathrm{Fe}^{2+}$. After seven days incubation, Mn concentration in the absence of added ferrous iron was $7.4 \pm 1.1 \mathrm{mg} / \mathrm{L}$ and $35.6 \pm 0.3 \mathrm{mg} / \mathrm{L}$ when ferrous iron was added. Likewise, the concentration of soluble Co was higher in ferrous iron-supplemented medium $(6.3 \pm 0.4 \mathrm{mg} / \mathrm{L})$ than in iron-free liquor $(2.0 \pm 0.3 \mathrm{mg} / \mathrm{L})$. These results imply that At. ferrooxidans caused the reductive dissolution of 
asbolane indirectly, via the generation of ferrous iron formed during the reductive dissolution of goethite. As with iron and nickel, bioprocessing of the lateritic ore under aerobic conditions resulted in far smaller amounts of both manganese and cobalt being solubilised than when anaerobic conditions were imposed (40 vs. $140 \mathrm{mg}$, and 8 vs. $24 \mathrm{mg}$, respectively, over 20 days). Over 95\% of the chromium in the limonite ore was also solubilised within the time frame of the experiments (data not shown). The source of this metal was the mineral chromite $\left(\mathrm{FeCr}_{2} \mathrm{O}_{4}\right)$ in which chromium has an oxidation state of +3 and iron of +2 (i.e., both metals are in reduced states). Dissolution of chromite was therefore considered to have occurred by direct acid dissolution. The reductive conditions of the bioprocess would preclude oxidation of the chromium released to its highly toxic +6 oxidation state, such as would occur in alternative processing options, such as high pressure acid leaching.

Figure 3. (a) Changes in concentrations of soluble manganese $(\bullet, \circ)$ and cobalt $(\boldsymbol{\Delta}, \Delta)$ in bioreactor cultures of At. ferrooxidans containing Ni laterite ore and elemental sulphur, incubated either under anoxic (solid symbols) or aerobic (open symbols) conditions); (b) correlation between the amounts of manganese and cobalt solubilised under anoxic conditions.

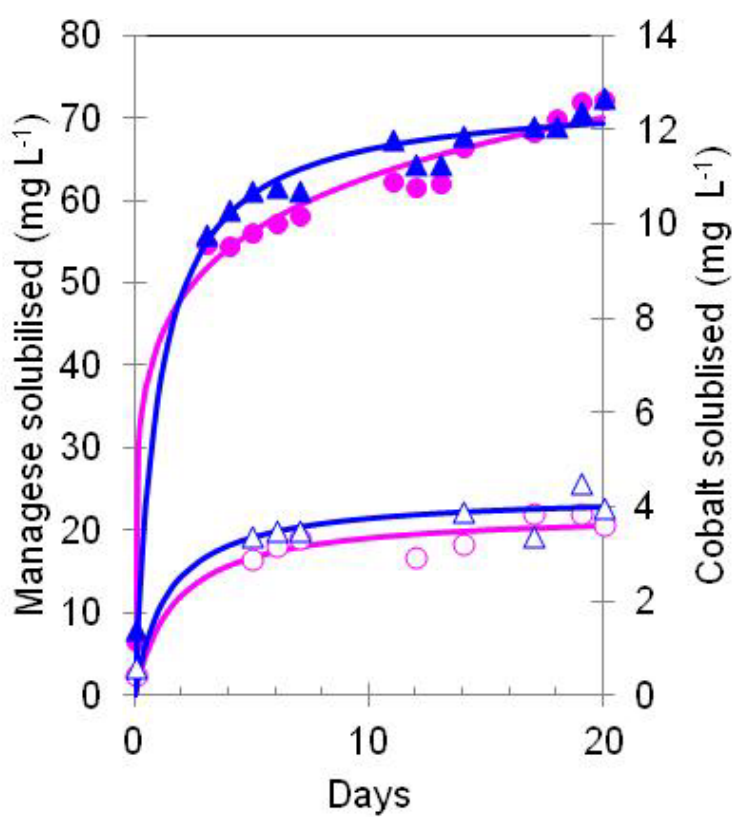

(a)

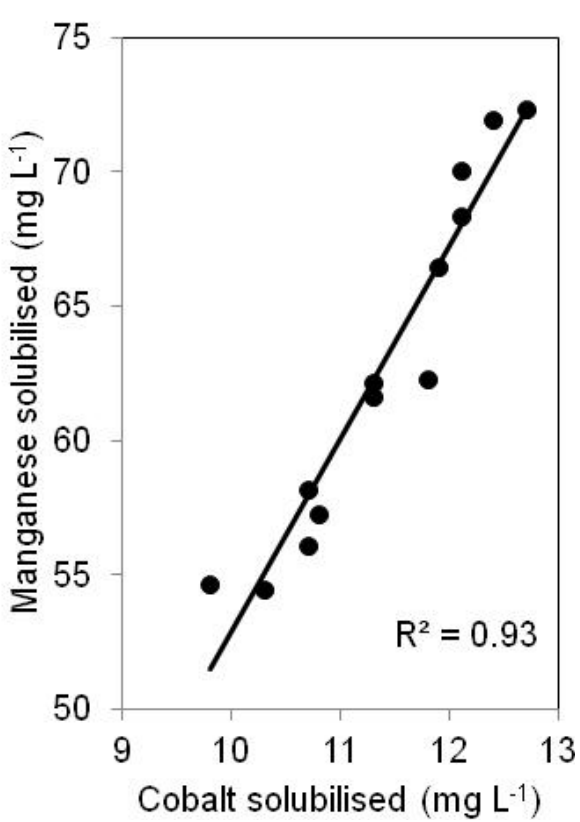

(b)

\subsection{Mass Balance of Metals in Untreated Ore and Bioleach Residues}

Leaching of metals from the nickel laterite, as determined by solution (leachate liquor) chemistry, was confirmed by X-ray fluorescence (XRF) analysis of metals in the residual, bioprocessed ore and also by dissolving the same residues in aqua regia and analysis of dissolved metals (Table 2). Analysis of the residual ore indicated that smaller amounts of nickel, cobalt and manganese had been extracted from the ore than indicated by analysis of the mineral leachates. This was due, at least in part, to the residues also containing undetermined amounts of sulphur (i.e., that which was not oxidized by the bacteria). 
Table 2. Recovery of metals during reductive dissolution of laterite by At. ferrooxidans based on X-ray fluorescence (XRF) analysis and dissolution by aqua regia of samples of ore before and after leaching. These are compared with recovery values determined by metal concentration in the leach liquor, which are based on the elemental composition of the laterite determined by BHP Billiton (nd, not determined).

\begin{tabular}{lccc}
\hline \multirow{2}{*}{ Mass balance based on: } & \multicolumn{3}{c}{ Metal recovery (\%) } \\
\cline { 2 - 4 } & Ni & Co & Mn \\
\hline XRF analysis & 46 & nd & 75 \\
aqua regia dissolution & 62 & 90 & 94 \\
leachate metal concentrations & 82 & 64 & 116 \\
\hline
\end{tabular}

\subsection{Implications of Bioreduction of Minerals by Acidophilic Microorganisms}

Metal-reducing microorganisms have considerable potential for use in biotechnologies [10]. This work has demonstrated that the reductive dissolution of a widespread ferric iron mineral, goethite, catalyzed by acidophilic microorganisms, can be an effective method of extracting metals from an oxidized ore. Such an approach for processing ferric iron ores could be generic. Several acidophilic bacteria capable of reducing soluble ferric iron have previously been shown to catalyze the reductive dissolution of a wide range of ferric iron minerals [9], and it has been demonstrate here that this is also the case for At. ferroooxidans. The novel approach demonstrated in this work has a number of advantages over hydro/pyrometallurgical processes and previously proposed techniques for bioprocessing nickel laterites, including: (i) the use of a relatively low-cost inorganic energy source (electron donor) to fuel the process; (ii) operation at ambient temperatures; (iii) much smaller biomass production compared to using heterotrophic microorganisms, such as fungi, as the sources of organic acids; and (iv) the low $\mathrm{pH}(<2)$ of the process, which promotes more rapid mineral dissolution than is achieved in less acidic conditions and ensures that the solubilised metals remain in solution, thereby facilitating their downstream separation and recovery.

In addition, bio-reduction of oxidized minerals in acidic solutions could also be applied beyond the mining industry, such as for the bioremediation of metal-contaminated soils, as well as in the recovery of metals from scrap electronics, where in currently proposed technologies metals are solubilised using biogenic sulphuric acid formed in situ, though recoveries are typically low due to the poor kinetics of acid dissolution of most oxidized minerals [11,12].

\section{Experimental Section}

\subsection{Ore Material}

A low-grade limonitic nickel laterite ore was sourced from a mine in Australia. The ore consisted mainly of the minerals quartz and goethite, along with smaller amounts of chromite, manganese oxide and magnesium silicate (Table 1$)$. The ore contained $0.4 \%(w / w)$ nickel, $56 \%$ of which was deported to the goethite fraction, with smaller amounts associated with the quartz (19\%) and the magnesium silicate $(18 \%)$. Other metals in the ore included iron, chromium, manganese and cobalt. Two particle 
size ranges of the ore were used in this study: "milled ore", screened to $<1 \mathrm{~mm}$ diameter, and "crushed ore", screened to $<6 \mathrm{~mm}$ diameter.

\subsection{Bacteria and Cultivation Conditions}

The mesophilic acidophile Acidithiobacillus ferrooxidans (strain NCIMB $11820^{\mathrm{T}}$ ) was used in these experiments. The bacterium was grown in a liquid medium containing minimal salts supplemented with trace elements [13], and cultures were incubated at $30^{\circ} \mathrm{C}$.

\subsection{Reduction of Nickel Laterite ore in Bioreactors}

At. ferrooxidans was grown under controlled conditions in a bioreactor ( $2 \mathrm{~L}$ working volumes) fitted with $\mathrm{pH}$ (set point $=1.8$ controlled using $1 \mathrm{M} \mathrm{H}_{2} \mathrm{SO}_{4}$ and $1 \mathrm{M} \mathrm{NaOH}$ ) and temperature control (set point $=30{ }^{\circ} \mathrm{C}$ ). The bacteria were initially grown aerobically (aerated at $1 \mathrm{~L} \cdot \mathrm{min}^{-1}$ ) with sulphur $(2.5 \% \mathrm{w} / \mathrm{v})$ as the electron donor, and when cell numbers had increased to $>5 \times 10^{8} \cdot \mathrm{mL}^{-1}$, the gas supply was switched to oxygen-free nitrogen (OFN), and $112.5 \mathrm{~g}$ of non-sterile, crushed nickel laterite ore screened to a particle size of $<6 \mathrm{~mm}$ was added. Samples were removed at regular intervals from the bioreactor for metal analysis, and the volume of acid added to maintain the $\mathrm{pH}$ was recorded. At the end of an experimental run, both gassing with OFN and stirring were stopped, and the remaining laterite ore was separated from the bulk of the residual sulphur by sedimentation. The ore was washed twice in sterile liquid medium and twice in deionized water before drying at $60{ }^{\circ} \mathrm{C}$. In one experiment, the culture was maintained under aerobic conditions by continuous aeration.

\subsection{Abiotic Solubilization of Manganese}

To assess whether the dissolution of the manganese (IV) mineral asbolane was catalyzed directly or indirectly (e.g., via the $\mathrm{Fe}^{2+}$ produced) by the bacteria, portions of the laterite ore $(0.5 \mathrm{~g})$ were added to $20 \mathrm{~mL}$ sterile growth medium at $\mathrm{pH}$ 1.8. Two of these received no additions, while two others were supplemented with ferrous sulphate $(20 \mathrm{mM}$, final concentration). No attempts were made to exclude oxygen. These were incubated at $30{ }^{\circ} \mathrm{C}$ and sampled periodically to measure soluble manganese concentrations, solution $\mathrm{pH}$ and $E_{h}$.

\subsection{Analytical Techniques}

Concentrations of metals (other than chromium) in samples that had been filtered through $0.2 \mu \mathrm{m}$ pore-sized polycarbonate filters were determined by high pressure ion chromatography (HPIC; [14]). Chromium concentrations were determined by atomic adsorption spectrophotometry. Ferrous iron concentrations were measured by a colorimetric assay using ferrozine [15]. Metal contents in the solid residues before and after leaching were analyzed by two separate methods: (i) ore samples were dissolved in aqua regia by heating at $100{ }^{\circ} \mathrm{C}$ for 1 hour, and the solubilised metals were determined by HPIC; and (ii) untreated and treated ore samples were analyzed using X-ray fluorescence by a commercial organization (X-ray Mineral Services Ltd., Colwyn Bay, UK). 


\section{Conclusions}

Bacterially-catalyzed reductive dissolution of an oxidized (lateritic ore) at low $\mathrm{pH}$ resulted in greatly enhanced leaching of nickel compared to acid dissolution alone. The critical reaction was the reduction of ferric iron to ferrous, catalyzed under anaerobic conditions by the acidophilic bacterium Acidithiobacillus ferrooxidans, using elemental sulphur as the electron donor. The microbial destruction of goethite under these conditions released the nickel that was associated with the ferric iron mineral, and this remained in solution due to the highly $(\mathrm{pH} 1.8)$ acidic nature of the leach liquor. The manganese (IV) mineral, asbolane, was also solubilised under the same condition, releasing the associated transition metal cobalt, though in this case, the mechanism was indirect, catalyzed by the ferrous iron produced by the bacteria. Chromium released (by acid dissolution) from the mineral chromite was present as the less toxic $\mathrm{Cr}$ (III) species in the leach liquor, as a consequence of the leach liquor being non-oxidative. This work has demonstrated a potential new direction for mineral bioprocessing, which could greatly expand the applications of biomining technologies.

\section{Acknowledgments}

Barrie Johnson is also grateful to the Royal Society (UK) for the provision of an Industrial Fellowship. Kevin Hallberg is grateful for financial support from the Biosciences, Environment and Agriculture Alliance (BEAA) between Bangor and Aberystwyth Universities.

\section{References}

1. Rawlings, D.E.; Johnson, D.B. Biomining; Springer-Verlag: Heidelberg, Germany, 2007.

2. Brierley, C.L. How will biomining be applied in future? Trans. Nonferrous Met. Soc. China 2008, 18, 1302-1310.

3. Rawlings, D.E.; Johnson, D.B. The microbiology of biomining: Development and optimization of mineral-oxidizing microbial consortia. Microbiology 2007, 153, 315-324.

4. Dalvi, A.D.; Bacon, W.G.; Osborne, R.C. The past and the future of nickel laterites. In Proceedings of Prospectors \& Developers Association of Canada (PDAC) 2004 International Convention, Trade Show \& Investors Exchange, Toronto, Ontario, Canada, 7-10 March 2004.

5. McDonald, R.G.; Whittington, B.I. Atmospheric acid leaching of nickel laterites review. Part I. Sulphuric acid technologies. Hydrometallurgy 2008, 91, 35-55.

6. McDonald, R.G.; Whittington, B.I. Atmospheric acid leaching of nickel laterites review. Part II. Chloride and bio-technologies. Hydrometallurgy 2008, 91, 56-69.

7. Johnson, D.B.; Hallberg, K.B. Carbon, iron and sulphur metabolism in acidophilic micro-organisms. Adv. Microb. Physiol. 2008, 54. 201-255.

8. Johnson, D.B.; Kanao, T.; Hedrich, S. Redox transformations of iron at extremely low pH: Fundamental and applied aspects. Front. Microbiol. 2012, 3, doi:10.3389/fmicb.2012.00096.

9. Bridge, T.A.M.; Johnson, D.B. Reduction of soluble iron and reductive dissolution of ferric iron-containing minerals by moderately thermophilic iron-oxidizing bacteria. Appl. Environ. Microbiol. 1998, 64, 2181-2186. 
10. Lloyd, J.R.; Lovley, D.R.; Macaskie, L.E. Biotechnological applications of metal-reducing microorganisms. Adv. Appl. Microbiol. 2003, 53, 85-128.

11. Brandl, H.; Faramarzi, M.A. Microbe-metal-interactions for the biotechnological treatment of metal-containing solid waste. China Particuolog. 2006, 4, 93-97.

12. Gadd, G.M. Metals, minerals and microbes: Geomicrobiology and bioremediation. Microbiology 2010, 156, 609-643.

13. Wakeman, K.; Auvinen, H.; Johnson, D.B. Microbiological and geochemical dynamics in simulated-heap leaching of a polymetallic sulphide ore. Biotech. Bioeng. 2008, 101, 739-750.

14. Nancucheo, I.; Johnson, D.B. Production of glycolic acid by chemolithotrophic iron- and sulphur-oxidizing bacteria and its role in delineating and sustaining acidophilic sulphide mineral-oxidizing consortia. Appl. Environ. Microbiol. 2010, 76, 461-467.

15. Lovley, D.R.; Phillips, E.J.P. Rapid assay for microbially reducible ferric iron in aquatic sediments. Appl. Environ. Microbiol. 1987, 53, 1536-1540.

(C) 2013 by the authors; licensee MDPI, Basel, Switzerland. This article is an open access article distributed under the terms and conditions of the Creative Commons Attribution license (http://creativecommons.org/licenses/by/3.0/). 